\title{
Dictynna
}

Dictynna

Revue de poétique latine

$11 \mid 2014$

Varia

\section{The Mixed Blessings of Bacchus in Virgil's Georgics}

Fiachra Mac Góráin

\section{(2) OpenEdition}

\section{Journals}

Electronic version

URL: http://journals.openedition.org/dictynna/1069

DOI: 10.4000/dictynna.1069

ISSN: 1765-3142

\section{Electronic reference}

Fiachra Mac Góráin, «The Mixed Blessings of Bacchus in Virgil's Georgics », Dictynna [Online], 11 | 2014, Online since 18 December 2014, connection on 10 September 2020. URL : http:// journals.openedition.org/dictynna/1069; DOI : https://doi.org/10.4000/dictynna.1069

This text was automatically generated on 10 September 2020 .

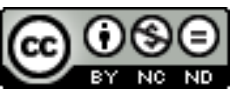

Les contenus des la revue Dictynna sont mis à disposition selon les termes de la Licence Creative Commons Attribution - Pas d'Utilisation Commerciale - Pas de Modification 4.0 International. 


\title{
The Mixed Blessings of Bacchus in Virgil's Georgics
}

\author{
Fiachra Mac Góráin
}

1 The subject of Bacchus and Bacchic themes in Augustan culture has recently been attracting considerable scholarly attention. ${ }^{1}$ One of the chief questions concerns the extent to which Bacchus is reintegrated into the Augustan discourse after the defeat of Mark Antony, who had adopted Dionysus as one of his patron gods. Virgil's poetry has been central to this discussion, and the Georgics have attracted their fair share of attention. ${ }^{2}$ And rightly so, since Bacchus has many functions within this poem: as god of fertility and vegetation; as a god of ritual, including mystery cult; as a god of poetic inspiration; and pointing outwards from the poem, as an element in the political propaganda of Virgil's time. ${ }^{3}$ In this article, I analyze Geo. 2.371-396, which contains the densest concentration of Bacchic references in the whole poem. I aim to show that in this one passage the figure of Bacchus unites and cuts across religion, agriculture, politics and poetics. I will argue that Bacchus is presented in a way that is largely positive and in line with the religious politics of the Augustan regime, but that there remain hints of the god's darker and destructive potential. I will contribute the suggestion that some of these hints arise from Virgil's allusions to Eratosthenes' Erigone, both in 2.380-96 and in a closely connected passage, the so-called vituperatio vini at 2.455-7. I begin by sketching in some context on the recent and roughly contemporary political resonances of Bacchus in Virgil's Rome.

2 It is notable that many of the major Augustan representations of Bacchus come after the Georgics, which are traditionally dated to 29 BCE. The Dionysian décor of the Villa della Farnesina, which might have belonged to Julia and Agrippa, is dated to the mid-20s BCE. ${ }^{4}$ Turpilianus' Liber issues celebrating the return of the Parthian standards do not appear until 18 BCE (see fig. 1). The Dionysian motifs on the frieze of the socalled 'Auditorium of Maecenas' were probably painted in the first decade CE. ${ }^{5}$ (Maecenas himself is reputed to have composed a dialogue entitled 'Symposium' in which Virgil and Horace appear, and in which Messala praised the strength of wine for 'lubricating the eyes, making everything more beautiful, and restoring the blessings of 
sweet youth. ${ }^{\prime}$ ) Nicias' painting of Dionysus in the Temple of Concordia Augusta cannot have been placed there before the temple's dedication in $10 \mathrm{CE} .{ }^{7}$ While the Dionysian plants on the Ara Pacis Augustae, ivy and vines, are dated to $14 \mathrm{CE} .{ }^{8}$ These testimonies suggest a gradual narrative of reintegration. The presence of Dionysus in public official contexts is unmistakable, if sometimes quite subtle. What, then, is the relationship between Virgil's poetic representation of Bacchus and these later material references to the god in Augustan contexts?

3 An important study by Riggs Alden Smith argues for the 'rehabilitation' of Bacchus in the Georgics: while Mark Antony had claimed Dionysus as his patron deity from 41 and throughout the 30s BCE, Virgil managed to rebrand and recuperate the god in the Georgics, divesting him of his more dangerous aspects, and making him suitable for incorporation in the Augustan programme - more as Liber pater than as a tragic Greek or Eastern Dionysus. ${ }^{9}$ The 'rehabilitation' of Bacchus can of course be traced back to the Eclogues, as Andrea Cucchiarelli has shown. ${ }^{10}$ It may even be possible to trace back the motif of Dionysus' defection from Antony to Octavian to the propaganda of $31 \mathrm{BCE}$ itself: Plutarch records that on the night before Octavian took Alexandria a noisy band of Bacchic revellers was heard leaving the city, and that this was interpreted as a sign that Antony's patron god was deserting him. ${ }^{11}$ The representation of Bacchus in the Georgics in a way that is broadly consistent with Augustan ideals might be thought of as following in this tradition.

On the other hand there were limits to the reintegration of Bacchus in Augustan Rome. The temple of Ceres, Liber and Libera on the Aventine had been burnt down in $31 \mathrm{BCE}$, the same year as the Battle of Actium, and even though Augustus began the restoration, it was not rededicated until $17 \mathrm{CE}$, by Tiberius. It is not entirely clear whether this temple should be counted among the eighty-two which Augustus claimed he had repaired at Res Gestae 20: duo et octoginta templa deum in urbe consul sextum ex auctoritate senatus refeci nullo praetermisso quod eo tempore refici debebat. The second half of the sentence would seem to rule out the neglect of such an important temple. But in light of the forty-five years between Octavian's sixth consulship and the temple's rededication, Miller is right to point out that it lay neglected for most of the Augustan principate. Zanker suggests that 'Some projects were more pressing than others.' ${ }^{12}$ Indeed, if Augustus had wanted to promote Bacchus unequivocally, then surely restoration of this temple would have been a priority.

5 Of course, a complex attitude, or even ambivalence, towards Bacchus/Liber in the Augustan regime is nothing new in the Roman imagination. It is based on the complexity of Bacchus himself, and on the fact that he was never fully Romanized, that he could always carry associations of the dubious outsider. As Cicero legislated for Roman religion in the Laws, he could warmly endorse the Eleusinian Mysteries of Iacchus as the most civilizing Greek influence on Rome, only then two chapters later to draw on the precedent of the Senate's severe clampdown on the Bacchanalia in 186 BCE. ${ }^{13}$ Cicero expresses no contradiction in the Laws between supporting Iacchus and citing the exclusion of Bacchus, probably because, as we learn in De natura deorum,one might distinguish between Liber the son of Semele and Liber the son of Ceres, who is familiar from the mysteries..$^{14} \mathrm{~A}$ similar distinction, this time implicit, was operative in the Bacchanalian Affair of 186 BCE. The Senate's clampdown on the Bacchanalia left the Liberalia undisturbed. But throughout Livy's substantial narrative of the events, which includes much detail on religious ritual and the specifics of senatorial policy, the 
historian has not felt any need whatsoever to point out a distinction between Bacchanalia and Liberalia. One was well established, and the other a recent phenomenon. Against the background of $186 \mathrm{BCE}$, then, the Augustan ambivalence towards Bacchus/Liber could be related to traditional Roman hostility to the threatening and un-Roman aspects of the god. But Mark Antony's recent degenerate posturings as Dionysus will have given Octavian particular pause: while Dionysus was too valuable a figure not to reappropriate, especially in light of his role in the myth of Alexander's conquest of the East, recuperation from Antony could only be achieved gradually and with caution.

While the presentation of Bacchus in Virgil's Georgics is substantially positive, the poem also reflects ambivalence, and further suggests that Bacchus is a difficult symbol to control. In summoning Bacchus to appear in his milder guise, Virgil hints at the god's dark side, which turns out to be irreppressible. In the hymnic invocation to Book 2, the poet invites the Lenaean father to join him in treading the new must for the vintage, but asks him to remove his tragic buskins, to put aside his wild guise in favour of a milder mien.

huc, pater o Lenaee, ueni, nudataque musto

tinge nouo mecum dereptis crura coturnis. (2.7-8)

7 While the invocation as a whole aligns poet and god, figuring the treading of the must as a metaphor for poetic composition, dereptis ... coturnis draws attention to the god's wild tragic aspect. ${ }^{15}$ Throughout the poem, Bacchus mostly cooperates in appearing without his buskins, but his blessings are mixed.

8 Let us turn now to our target passage: advice on protecting young trees from pests, which modulates into the digression on the rural worship of Bacchus.

Texendae saepes etiam et pecus omne tenendum, praecipue dum frons tenera imprudensque laborum; cui super indignas hiemes solemque potentem siluestres uri adsidue capreaeque sequaces inludunt, pascuntur oues auidaeque iuuencae.

frigora nec tantum cana concreta pruina aut grauis incumbens scopulis arentibus aestas, quantum illi nocuere greges durique uenenum dentis et admorsu signata in stirpe cicatrix. non aliam ob culpam Baccho caper omnibus aris caeditur et ueteres ineunt proscaenia ludi, praemiaque ingeniis pagos et compita circum Thesidae posuere, atque inter pocula laeti mollibus in pratis unctos saluere per utres nec non Ausonii, Troia gens missa, coloni uersibus incomptis ludunt risuque soluto, oraque corticibus sumunt horrenda cauatis, et te, Bacche, uocant per carmina laeta, tibique oscilla ex alta suspendunt mollia pinu. hinc omnis largo pubescit uinea fetu, complentur uallesque cauae saltusque profundi et quocumque deus circum caput egit honestum. ergo rite suum Baccho dicemus honorem carminibus patriis lancesque et liba feremus, et ductus cornu stabit sacer hircus ad aram pinguiaque in ueribus torrebimus exta colurnis. 
There are hedges to be laid, to keep out each and any beast, especially when the leaves are delicate and unaccustomed to attack, winter's cruelty or the worst extremes of summer, not to mention rampant buffalo and deer nibbling havoc there, or sheep and brawly heifers that eat their fill. 375

No winter weather, its hardest frosts, nor summer's heat that splits the stones, did hurt to them to equal herds and flocks, their toothmarks' harm, the scars they've inscribed in the bark. And they're the why, such transgressions, a goat is sacrificed 380 on every altar to the wine god - since our elders started to stage plays and the sons of Theseus rewarded talent along the highways and byeways and, with drink taken, took to hopping here and there, a dance on greasy hides, and toppling in soft grass. So too, Ausonian settlers - who came from Troy - $\quad 385$ recited their rough-hewn verse to entertain the masses, and put on scary masks cut out of bark and called on you, Bacchus, in rousing song, and in your honour dangled from the tips of pines tender tokens. And it ensues that every vineyard crests and fills, $\quad 390$ valleys teem, and deep ravines -

anywhere the god took in with his goodly gaze.

Therefore, as is only right, we accord to Bacchus due respect with songs our fathers sang and trays of baked offerings and, led by the horn, the sacrifical puck is set before the altar 395 and his spewling innards roasted on hazel skewers. (tr. Peter Fallon)

There is already something Dionysian about the many swerves and shifts in this topsyturvy passage. ${ }^{16}$ Bacchus presides over a series of bizarre transitions from extreme weather to four-footed pests, to the aetiology of the goat sacrifice in the god's honour, to the origins of the Attic tragic festival involving askoliasmos (dancing on an oiled goatskin), to its Italian equivalent with its ribald songs and oscillatio (ritual hanging of masks), and back again to feasting at the goat sacrifice. Commentators since Heyne (on 2.380) have focussed on the transitions as one of the main features in need of explanation. The scenes unfold through the accumulation of detail, introduced by et, que, or atque, or a new scene is appended by means of a deductive particle and elaborated, or the scene changes through a formula of contrast or analogy. ${ }^{17}$ For all its variety, the passage is unified in that all of the details from the goat sacrifice to the end of the passage are at home in the world of Dionysian ritual. The only really puzzling transition is nec non Ausonii at 2.385: exactly what is the relationship between the Athenian tragic festival and its Italian counterpart? Virgil chooses to leave this vague: he establishes the pre-Hellenic credentials of the Italian festival, ${ }^{18}$ while nonetheless elevating it by adducing a similarity with the Athenian Dionysia.

The passage is in harmony with the general religious orientation of the Georgics, in which farming and worship of the gods are closely connected. This connection in turn squares well with a reading of the Georgics as supporting Augustus' religious reforms and renewal of interest in agriculture. Numbered among the farmer's tools in the previous book (designated as arma at 1.160) are ones which evoke Eleusinian ritual the waggon of the Eleusinian mother, the wickerwork of Celeus, and the mystical winnowing-fan of Iacchus. ${ }^{19}$ These references suggest a close alignment between agricultural work and worship of the gods. While our passage does not suggest mystery ritual as such, it does move from worship to fertility, from a punitive sacrifice of a goat 
in honour of Bacchus to the god's epiphany, suggested by the god creating natural abundance wherever he turns his beneficent face, quocumque deus circum caput egit honestum (392). ${ }^{20}$ Moreover, following on from the conjunction of Ceres and Iacchus in the Eleusinian mysteries, it is clear that the festival in Book 2 functions as a counterpart of the festival of Ceres at 1.338-50, which is an amalgam of Cerealia and Ambarvalia. Bacchus and Ceres are often paired, as gods of wet and dry food, and have been closely linked since their joint invocation in the proem to Book 1, Liber et alma Ceres (1.7). ${ }^{21}$ Their harmonius pairing contrasts with an alternative tradition, preserved by Pliny the Elder, of a great contest between the two over patronage of Campania, summum Liberi Patris cum Cerere certamen. ${ }^{22}$

11 Aside from the general idea of Bacchic worship, it is notably unspecific which festival is being celebrated here, and it seems that Virgil has composed a literary synthesis of elements from different rituals, some of which have Augustan resonances. Thesidae (383) and their prize for theatrical contests evoke, as we have seen, the Athenian Dionysia, and there is some debate as to whether the central element in our passage, the goat sacrifice, was also an element in the Athenian Dionysia, either the city or the country festival..$^{23} \mathrm{Be}$ that as it may, the killing of a goat in honour of Bacchus is is not attested for any Roman festival, even though the motif is well established in the literary and artistic record, and mentioned by Varro in De re rustica. ${ }^{24}$ Some exegetes of the Athenian Dionysia have also wished to see the goat sacrifice as a central element in the worship of Bacchus. The motif also occurs in an epigram of Evenus of Askalon, which is quoted in a Pompeian wall painting of a goat nibbling vines, shortly before being led to sacrifice:

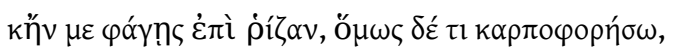

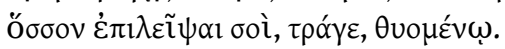

"And even if you nibble me down to the root, nonetheless I will still bear enough

fruit to pour a libation over you, goat, when you're being sacrificed." ${ }^{25}$

Ovid translated this epigram, closely echoing Virgil's phrasing from the Georgics, in his aetiology of animal sacrifice in the Fasti:

rode, caper, uitem: tamen hinc, cum stabis ad aram,

in tua quod spargi cornua possit erit. ${ }^{26}$

Meuli argued hard that what we have in our passage is the Compitalia, and sure enough there is a hint at this in pagos et compita circum (2.382). ${ }^{27}$ Augustus was later to restore the ludi compitalicii, which had fallen into disrepair, and to direct that the Lares compitales be festooned with flowers twice a year. ${ }^{28}$ On the other hand, the reference to liba at 2.389 suggests the Liberalia, named from the honey cakes (liba) according to certain traditions preserved by Varro in De lingua latina and Ovid in the Fasti. ${ }^{29}$ In a different work by Varro, the Antiquitates rerum divinarum, which was composed not long before the Georgics in $45 \mathrm{BCE}$, there was an account of a phallophoric fertility festival in honour of Liber. St. Augustine is our source for this testimony, and a derisive source he is too, in his polemic against pagan religion in City of God.

...Italiae compitis quaedam dicit sacra Liberi celebrata cum tanta licentia turpitudinis, ut in eius honorem pudenda virilia colerentur, non saltem aliquantum verecundiore secreto, sed in propatulo exultante nequitia. Nam hoc turpe membrum per Liberi dies festos cum honore magno plostellis inpositum prius rure in compitis et usque in urbem postea vectabatur. In oppido autem Lavinio unus Libero totus mensis tribuebatur, cuius diebus omnes verbis flagitiosissimis uterentur, donec illud membrum per forum transvectum esset atque in loco suo quiesceret. Cui membro inhonesto matrem familias honestissimam palam coronam 
necesse erat inponere. Sic videlicet Liber deus placandus fuerat pro eventibus seminum, sic ab agris fascinatio repellenda...

...there are certain rites of Liber that [Varro] says are celebrated at Italian crossroads with such shameful abandon that the private parts of the male are worshipped in the god's honour, and not even in secret, out of some deference to modesty, but openly and with wantonness running riot. Yes indeed, during Liber's festal days this disgusting member would be exhibited on a waggon with great honour, and carried first around the crossroads in the countryside, and then brought all the way into the city. In the town of Lavinium they even dedicated a whole month to Liber, and during these days they all used such disgraceful language until that member had been carried through the forum and come to rest in its own place. Then the most respectable woman, a mother of a family, had to place a garland on said dishonourable member. In this way, supposedly, the god Liber was to be propitiated so that all would turn out well with the seeds; in this way the hex needed to be warded off the fields... (City of God 7.21.2-4, tr. FMG)

The two rites have a few points in common: in both cases the god is worshipped and propitiated in a ribald ceremony ${ }^{30}$ to promote fertility; ${ }^{31}$ and both involve worship at crossroads, compita. ${ }^{32}$ On the other hand, Varro is talking about a specific local festival from Lavinium (where, incidentally, a painting representing Bacchic worship was recently discovered ${ }^{33}$ ), while Virgil's festival is delocalized, omnibus aris (380), with a general Italian feel, but including also Athenian references. More importantly, Virgil's festival seems by far the more sanitized, despite the fact that it has sacrifice as its centrepiece. The suppression of the phallophoric element could be seen as in line with Augustan religious conservatism.

15 Well, so far, so Augustan, but there are two ritual elements which do not seem to fit into any of the festivals mentioned so far: askoliasmos and oscillatio. Especially when taken together, these ritual motifs seem to point to the myth of Icarius and Erigone, and to the Attic festival of the Aiôra. Many scholars have discussed the presence of Eratosthenes' Erigone in the Georgics, which may be flagged up by the reference to a catasterized Erigone in the proem to Book 1 at $1.33 .{ }^{34}$ For the remainder of this paper, I add some observations to the study of these allusions, and I go beyond existing treatments in suggesting a political interpretation.

16 Eratosthenes' Erigone, which the author of the treatise on the sublime called 'an

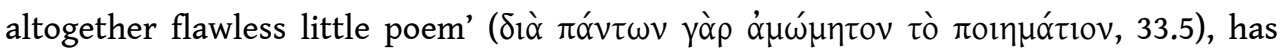
been variously reconstructed from the few meagre fragments which survive, and from surviving narrative sources for the myth, in particular Hyginus and Nonnus. ${ }^{35}$ Servius gives a version of the myth in his note on oscilla in Georgics 2.389, though without mentioning Eratosthenes. The poem seems to have narrated Dionysus' visit to Icarius and Erigone in Attica, his introduction of the vine, Icarius' death at the hands of drunken rustics, the dog Maera leading Erigone to her dead father, Erigone's ensuing grief and suicide, the resulting plague of virgil suicides, and the resolution of this plague by the institution of the festival of the Aiôra. The poem may have ended with the catasterism of Icarius (Bootes), Erigone (the maiden), and the faithful dog (Sirius). Virgil mentions the three stars in book $1 .^{36}$ Reconstructions of the Erigone would like to see in this poem aetiologies for the goat sacrifice, askoliasmos, the Athenian tragic festival, and the rite of oscillatio.

17 Some level of allusion to the Erigone in our passage seems to me a likely and attractive possibility. Hyginus' story of Icarius and Dionysus and our Georgics passage share the viticultural context, the killing of the goat followed by askoliasmos, and the hanging of 
masks. Erigone also seems to have cast Bacchus as a didactic figure, which is how Liber is invoked in the proem to Book 1. The myth of Dionysus' visit to Icarius is often found paired with the myth of Ceres' introduction of ploughing, and this would be consistent with the pairing of Ceres and Bacchus in the Georgics. ${ }^{37}$ The density of aetia posited for the Erigone would place it squarely in the Callimachean tradition, in which Virgil's Georgics also insert themselves. ${ }^{38}$ Moreover, allusion to the Erigone would account for the very miscellaneous content of our passage, and for the elliptical transitions between its different sections: if Virgil expected his readers to know the Hellenistic model, then in Hellenistic style he could dispense with explaining the connections. ${ }^{39}$

Virgil seems closest to Eratosthenes' Erigone in the following echo (I give the context from Hyginus which preserves the quotation from Eratosthenes):

non aliam ob culpam Baccho caper omnibus aris

caeditur et ueteres ineunt proscaenia ludi,

praemiaque ingeniis pagos et compita circum

Thesidae posuere, atque inter pocula laeti

mollibus in pratis unctos saluere per utres. (2.380-4)

Hyginus, Astronomica 2.4.153-160 (Arctophylax), ed. Viré.

Qui cum sevisset vitem et diligentissime administrando floridam facile fecisset, dicitur hircus in vineam se coniecisse et quae ibi tenerrima folia videret decerpsisse; quo facto Icarum [MSSIcarium] animo irato tulisse eumque interfecisse et ex pelle eius utrem fecisse ac vento plenum praeligasse et in medium proiecisse suosque sodales circum eum saltare coegisse. Itaque Eratosthenes ait:

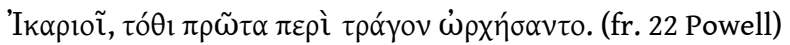

When he [Icarius] had sown the vine and had made it flourish easily through the most diligent care, it is said that a goat burst into the vineyard and nibbled the young leaves he saw there; they say that Icarius was very angry at this, and so he killed the goat and made a wineskin from its hide, tied it up full of air and threw it down in front of his companions and made them dance around it. So Eratosthenes says:

At Icaria for the first time they danced around a goat.

The text of the quoted line is uncertain, and I print here Powell's text rather than Viré's or Rosokoki's. ${ }^{40}$ What is perhaps most remarkable about Virgil's allusion is that the Erigone myth, and probably also Eratosthenes' poem, narrates a disastrous outcome to the introduction of wine. In line with this, there may be another allusion to Eratosthenes' Erigone at Bacchus' lowest point in Georgics 2, the famous vituperatio vini which concludes the praises of trees, 2.454-7.

quid memorandum aeque Baccheia dona tulerunt?

Bacchus et ad culpam causas dedit; ille furentis

Centauros leto domuit, Rhoecumque Pholumque

et magno Hylaeum Lapithis cratere minantem.

What offering from Bacchus are more worthy of remembering?

Bacchus! He it was who gave cause to crime, he who smote

the maddened Centaurs with a moral blow - Rhoecus, Pholus,

and Hylaeus, the one who'd deranged the Lapiths with a power of wine. (tr. Peter

Fallon)

The passage glances back at the goat sacrifice through the word echo in culpam (cf. 2.380 non aliam ob culpam), and indeed it gives a disturbingly different perspective on the Dionysian experience from the benign and beneficent aspect we see at the Italian festival. Some readers since before Servius have tried to whitewash the lines so that they are less critical of Bacchus. ${ }^{41}$ It is wrong to do so, as the lines give expression to Bacchus' problematic aspects, which are present, though kept in check, elsewhere in 
the book. He is a complex symbol, hard to control. ${ }^{42}$ At the very least the vituperatio vini suggests the importance of tempering wine with water, as prescribed in the proem to Georgics 1

Liber et alma Ceres, uestro si munere tellus

Chaoniam pingui glandem mutauit arista,

poculaque inuentis Acheloia miscuit uuis (1.7-9)

21 The two gods are chiastically celebrated for their gifts to civilization, viticulture and agriculture, but it is specified that the gift of Bacchus should be mixed with water. ${ }^{43}$ Christopher Nappa has argued that it was drinking neat wine that led to the centaurs' brawl. ${ }^{44} \mathrm{~A}$ number of discussions of Bacchus in the Georgics point to the praises of country life that conclude the book, and note that lines 528-9, socii cratera coronant, I te libans, Lenaee, uocat, seem to 'correct' the Centaurs' mistake: the word-echo of cratere minantem in cratera coronant suggests that correct sympotic protocol has been reinstated. ${ }^{45}$ The Greek model usually invoked for the vituperatio vini is Homer, Odyssey 21.293-8, Antinous' taunt to the disguised Odysseus that wine had addled his wits, as it does the wits of anyone who gulps it down too greedily and without due measure (294,

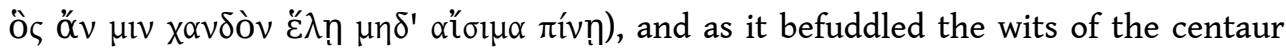
Eurytion, who caused trouble in the house of Peirithous. Indeed elsewhere in the Odyssey we encounter the perils of drinking unmixed wine. ${ }^{46}$ Virgil seems to have found a variation on the theme in Eratosthenes' Erigone:

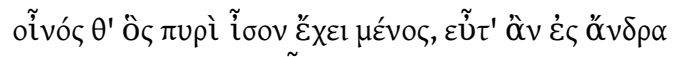

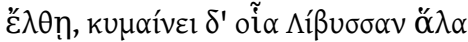

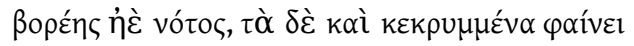

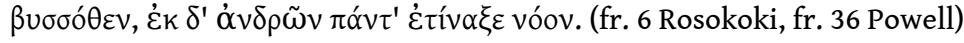

"Wine has as much strength as fire, when it goes into a man, and just as the north or south wind makes the Libyan sea boil, it reveals what was buried deep down; and has put men right out of their minds." (tr. FMG)

Actually the preserving contexts only tell us that these lines are by Eratosthenes, not specifying that they come from Erigone, and accordingly Powell places the fragment among the dubia. ${ }^{47}$ Beyond the question of attribution there is debate as to whether the lines may have come from a gnomic reflection (a warning uttered by Dionysus?) on the strength of wine, or from the narrative of the rustics' killing of Icarius. ${ }^{48}$ One final fragment of Eratosthenes which is probably from the Erigone shares lexical similarity with the vituperatio vini:

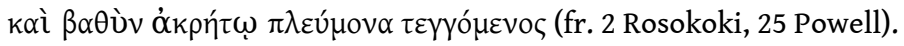

"and wetting the depth of the lung with unmixed [wine]" (tr. FMG)

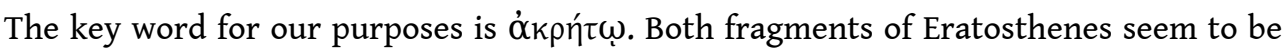
addressing the importance of mixing wine with water in the interests of civilized consumption. Even though the grammatical form is entirely different, this word seems to resonate in the Georgics, in the use of the word crater at cratere minantem (2.457) and cratera coronant (2.528).

How should we interpret the allusion to Eratosthenes' Erigone? Thibodeau has suggested that Virgil gives us a Bacchus more dignified than Eratosthenes' by not including a reference to 'the more frivolous and fabulous elements' of Eratosthenes'poem. ${ }^{49}$ This is a reasonable interpretation as far as the digression on the goat sacrifice is concerned, and one that is consistent with Smith's thesis of rehabiliation. On the other hand, the digression looks closely to the vituperatio vini, and two further possible allusions to Eratosthenes' Erigone suggest precisely the dimensions 
of the myth which are not mentioned in the movement on the worship of Bacchus: the dangers of drunkenness. Bacchus turns out to be a god of mixed blessings.

We do not know how the Erigone related to its Ptolemaic context, but we do know that Dionysus was very important in the Ptolemies' religious politics. ${ }^{50}$ Dionysus seems to have become connected with stories of the eastern conquests of Alexander very soon after Alexander's death. ${ }^{51}$ In Egypt there was the added element of the identification between Dionysus and Osiris, which is attested as early as Herodotus $(2.42,47)$. A number of the Ptolemies adopted the cognomen Dionysus, and it would appear from Ptolemy II Philadelphus' Grand Procession that the god was a symbol of wealth and fertility, closely controlled by the monarchs. Later Ptolemy IV Philopator enjoined a duty of registration on all practitioners of the rites of Dionysus. ${ }^{52}$ How, then, did a poem that culminated in the disastrous consequences of Dionysus' introduction of viticulture fit into this Ptolemaic context? One possible explanation is that there is no particular political connection, and that the Erigone sits in a well established poetic tradition on the perils associated with Dionysus, from the seventh Homeric hymn through to Aeschylus' Lycurgus trilogy and Euripides' Bacchae. But perhaps a closer historical precedent to the dangers of Dionysian drunkennness may be found in reports of Alexander's drunken killing of Kleitos, on a day when he had neglected to observe the worship of Dionysus. Ancient sources from Curtius to Plutarch and Arrian report that Alexander was not unwilling to ascribe his murderous drunken outburst to the wrath of Dionysus, who had been neglected in the libations. ${ }^{53}$ It is interesting and important that this story of a negative relationship between Alexander and Dionysus precedes and coexists with the more positive story of Dionysus as a model for Alexander's eastern conquests and Indian triumph. Alexander's relationship with Dionysus is thus a complex and dynamic one. ${ }^{54}$ Sure enough, in his seventeenth-century commentary on the Georgics, La Cerda cites Curtius' version of the murder of Kleitos alongside Homer's speech of Antinous (Od. 21.293-8) on the drunken centaur among parallels for the vituperatio vini. ${ }^{55}$ We know, of course, that in adopting Dionysus as his patron god, Antony was partly taking after Alexander, and equally that it was the god's Alexandrian pedigree that made him attractive to Octavian after the defeat of Antony. But it would seem that the association with Dionysus backfired on Antony in the counterpropaganda of the age. Plutarch reports that in Ephesus, some citizens charged him with being Dionysus the Raw Eater and the Savage. ${ }^{56}$ The testimony to Antony's De sua ebrietate (Pliny, HN 14.22) gives rise to the impression that Antony's identification with Dionysus backfired, such that he had to pen an apologia. ${ }^{57}$ And we have noted the story, also recorded by Plutarch, of the god's 'desertion' of Antony before the Battle of Actium. The possibility of a historical allusion in the vituperatio vini to Alexander's murder of Kleitos alongside the motif of murderous drunkenness in the myth of Icarius and Erigone would indeed seem to suggest the mixed blessings of Bacchus, a god difficult to control.

The last two appearances of Bacchus in the Georgics illustrate the poem's ambivalence towards him. During the Aristaeus epyllion we learn that Ciconian mothers ripped Orpheus apart in an act of ritual sparagmos (4.520-2). A little later, Aristaeus completes the ritual of the bugonia, and arguably there is an allusion to Bacchus in that the newly regenerated bees land on a cluster of grapes (4.458)..$^{58}$ While the very last reference lends itself to a benign reading, the penultimate reference to destructive orgiastic madness is not far behind. While Bacchus is mostly a god of fertility and abundance in 
the Georgics, and while he is mostly rehabilitated, his dangerous and menacing aspect in the end proves irreppressible. ${ }^{59}$

Fig. 1, One of Turpilianus' coins of 18 BCE: obv. head of Liber with ivy in hair; IIVIR TURPILIANUS. rev. kneeling Parthian with standard; CAESAR AUGUSTUS SIGN. RECE. RIC I 287; BMCRE 10; RSC 485 .

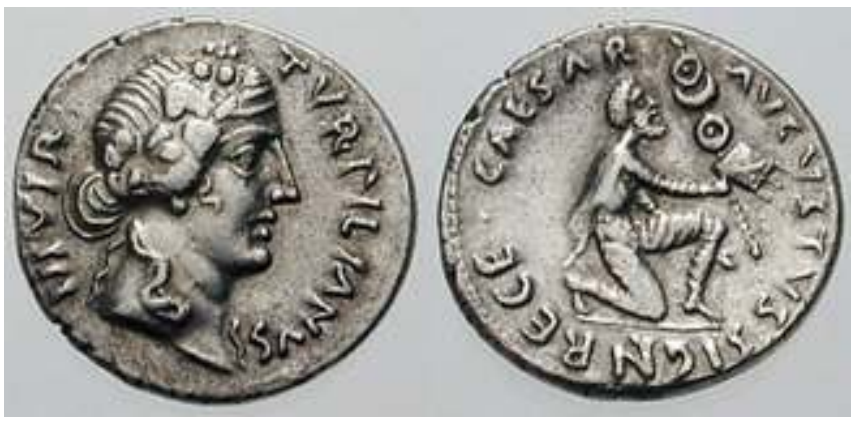

\section{BIBLIOGRAPHY}

Atteni, L. 2002. Frammenti di affresco con scene d'iniziazione dionisiaca. Velletri.

Becher, I. 1976. 'Augustus und Dionysos - ein Feindverhältnis?', Zeitschrift für ägyptische Sprache und Altertumskunde, Berlin Akad.-Verl. 103, 88-101.

Bocciolini Palagi, L. 2007. La trottola di Dioniso. Motivi dionisiaci nel vii libro dell' Eneide. Bologna. Bosworth, A. B. 1980, A Historical Commentary on Arrian's History of Alexander (Oxford, 2 vols.). Broggiato, M. 2014. 'Eratosthenes, Icaria, and the Origins of Tragedy.' Mnemosyne 2014, 1-15.

Castriota, D. 1995. The Ara Pacis Augustae and the imagery of abundance in later Greek and early Roman imperial art. Princeton.

Cerda, J. L. de la. 1619. P. Virgilii Maronis Bucolica et Georgica argumentis, explicationibus, notis illustrata. Lyons.

Coarelli, F. 1993. 'Ceres, Liber, Liberaque, Aedes; Aedes Cereris.' LTUR I, 260-261.

Cucchiarelli, A. 2011. 'Virgilio e l'invenzione dell' età augustea' (Modelli divini elinguaggio politico dalle 'Bucoliche' alle 'Georgiche').' Lexis 29, 229-274.

Cucchiarelli, A. (ed.) - Traina, A. (tr.) 2012. Publio Virgilio Marone. Le Bucoliche. Introduzione e commento di Andrea Cucchiarelli. Traduzione di Alfonso Traina. Rome.

Cucchiarelli, A. 2012a. 'Ivy and Laurel. Divine Models in Virgil's Eclogues.' HSCP 107, 155-78.

Deremetz, A. 2000. 'La terre inspirée et le poète-paysan.' Noesis 4, 155-179.

Erren, M. 2003. P. Vergilius Maro: 'Georgica.' Band 2. Kommentar. Heidelberg. 
Fabre-Serris, J. 2009. 'Figures romaines de Dionysos à la fin du $\mathrm{I}^{\mathrm{er}}$ siècle av. J.-C..' In Rembrandt Duits - François Quiviger (eds.), Images of the Pagan Gods. Papers of a Conference in Memory of Jean Seznec, Warburg Institute Colloquia 14, 281-296.

Fallon, P. 2004. The Georgics of Virgil. Oldcastle.

Feldherr, A. 2010 “"Dionysiac Poetics" and the Memory of Civil War in Horace's Cleopatra Ode', in B. Breed, C. Damon, A. Rossi (eds.) Citizens of Discord (Oxford), 223-32.

Frentz, W. 1967. Mythologisches in Vergils Georgica. Beiträge zur klassischen Philologie 21. Meisenheim/Glan.

Freyburger, G. 2013. 'Liber-Bacchus dans la poésie augustéenne: du passé de Rome au temps d'Auguste.' In Poésie augustéenne et mémoires du passé de Rome : en hommage au professeur Lucienne Deschamps / textes réunis par Olivier Devillers \& Guillaume Flamerie de Lachapelle. - Paris/Bordeaux, 93-99.

Freyburger-Galland, M.-L. 2009. 'Political and Religious Propaganda between 44 and 27 BC.' Vergilius 55, 17-30.

Fuhrer, T. 2011. 'Inszenierungen von Göttlichkeit: die politische Rolle von Dionysos/Bacchus in der Römischen Literatur.' In R. Schlesier, ed., A different god?: Dionysos and ancient polytheism. Berlin, 373-389.

Gale, M. R. 2000. Virgil on the Nature of Things. Cambridge.

Geus, K. 2002. Eratosthenes von Kyrene. Studien zur hellenistischen Kultur- und Wissenschaftsgeschichte. Munich.

Giusti, E. forthcoming in 2014. 'Horace's Epode 9 and Its General(s') Confusion.' In P.Bather C.Stocks (edd.), Horace's Epodes: Literary Traditions and Contexts, Oxford.

Goukowsky, P. 1981. Essai sur les origines du mythe d'Alexandre (336-270 av. J.-C.), Nancy, 2 vols., I Les origines politiques, II Alexandre et Dionysos.

Gowers, E. (forthcoming). 'Under the Influence: Bacchus and Maecenas in Virgil's Second Georgic.' In P. Hardie, ed., Augustan Poetry and the Irrational. Oxford.

Grimal, P. 1980. ‘La vigne et l'olivier. Réfléxions sur le chant II des <<Géorgiques>>. Bulletin de l'Association Guillaume Budé 2, 171-85.

Harder, A. (ed.), 2012. Callimachus: Aetia. Oxford. 2 vols.

Hardie, A. 2002. 'The Georgics, the Mysteries and the Muses at Rome.' PCPhS 48, 175-208.

Henrichs, A. 2013. 'Bacchus.' In R. F. Thomas - J. M. Ziolkowski (edd.), The Virgil Encyclopedia. Cambridge, MA.

Heyne, Chr. G. (ed.), rec. Wagner, G. P. E. (1830) P. Virgili Maronis Opera, vol. 2. Leipzig.

Hollis, A. S. 1991. ‘A New Fragment of Eratosthenes' Erigone?' ZPE 89, 27-29.

Hopkinson, N. 1997. 'The Erigone of Eratosthenes.' review of Rosokoki 1995. CR 47, 29-31.

Johnston, P. A. 2009. 'The Mystery Cults and Virgil's Georgics.' In G. Casadio - P. A. Johnston (edd.), Mystic Cults in Magna Graecia. Austin, Texas, 251-273.

Kellum, B. A. 1990. 'The City Adorned: Programmatic Display at the Aedes Concordiae Augustae. In K.A. Raaflaub-M. Toher eds., Between Republic and Empire. Interpretations of Augustus and His Principate, Berkeley-Los Angeles-Oxford, 276-96. 
Kellum, B. A. 1994. 'What we see and what we don't see. Narrative structure and the Ara Pacis Augustae.' Art History 17, 26-45.

Kern, O. 1916. 'Iakchos.' In Pauly-Wissowa (ed.) RE 9, 613-622.

Klinger, F. 1967. Virgil. Bucolica. Georgica. Aeneis. Zurich.

Krummen, E. 2004. 'Dido als Mänade und tragische Heroine. Dionysische Thematik und Tragödientradition in Vergils Didoerzählung.' Poetica 36, 25-69.

Maass, E. 1883. Analecta Eratosthenica. Berlin.

Mac Góráin, F. 2013. 'Virgil’s Bacchus and the Roman Republic.' In D. Nelis - J. Farrell eds., Augustan Poetry and the Roman Republic. Oxford, 124-45.

Mac Góráin, F. 2014. 'Apollo and Dionysus in Virgil.' Incontri di filologia classica 12 (2012-13), 191-238.

Marasco, G. 1992. ‘Marco Antonio “nuovo Dionisos” e il De sua ebrietate.' Latomus 51, 538-548.

Mattingly, H. 1923. Coins of the Roman Empire in the British Museum I. London.

Merkelbach, R. 1963. 'Die Erigone des Eratosthenes.' In Miscellanea di studi alessandrini in memoria di Augusto Rostagni. Turin, 469-526.

Meuli, K. 1955. 'Altrömischer Maskenbrauch.' MH 12, 206-35.

Miller, J. F. 2002. 'Ovid's Liberalia.' In G. Herbert-Brown ed., Ovid's Fasti. Historical Readings at its Bimillennium. Oxford, 199-224.

Morgan, Ll. 1999. Patterns of Redemption in Virgil's Georgics. Cambridge.

Mynors, R. A. B. (ed.) $1972^{2}$. P. Vergili Maronis Opera. Oxford.

Nappa, C. 2005. Reading after Actium: Vergil's Georgics, Octavian, and Rome. Ann Arbor.

Nock, A. D. 1928. 'Notes on Ruler-Cult, I-IV.' JHS 48, 21-43.

Pelling, C. B. R. 1988. Plutarch. Life of Antony. Cambridge.

Pollini, J. 2012. From republic to empire : rhetoric, religion, and power in the visual culture of ancient Rome. Norman, $\mathrm{OK}$.

Rose, H. J. 1924. 'The Departure of Dionysus.' Annals of Archaeology and Anthropology 11, 25-30.

Rosokoki, A. (ed.) 1995. Die Erigone des Eratosthenes. Eine kommentierte Ausgabe der Fragmente.

Heidelberg.

Sauron, G. 1994. Quis deum ? : l'expression plastique des idéologies politiques et religieuses à Rome à la fin de la République et au début du Principat. BEFAR 285. Rome.

Sauron, G. 2000. L'histoire végétalisée : ornement et politique à Rome. Paris.

Schiesaro, A. 2009. 'Horace's Bacchic Poetics.' In L. B. T. Houghton - M. Wyke eds., Perceptions of Horace, Cambridge, 61-79.

Scott, K. 1929. 'Octavian's Propaganda and Antony's De Sue Ebrietate.' CPh 24, 133-41.

Seaby, H. A. 1978. Roman Silver Coins. Vol. 1. London.

Shechter, S. 1976. 'The Aition and Virgil's Georgics.' TAPA 105, 347-391.

Smith, R. A. 2007. 'In vino civitas: the rehabilitation of Bacchus in Vergil's Georgics.' Vergilius 53, $52-86$. 
Solmsen, F. 1947. 'Eratosthenes' Erigone: A Reconstruction.' TAPA 78, 252-275.

Sutherland, C. H. V. 1984 [1923]. Roman Imperial Coinage. vol. 1. London.

Thibodeau, Ph. 2011. Playing the farmer: representations of rural life in Vergil's Georgics. Berkeley, CA.

Thomas, R. F. (ed.) 1988. Virgil. The Georgics. Cambridge. 2 vols.

Thomas, R. F. 1995. ‘Vestigia ruris: Urbane rusticity in Virgil’s Georgics.' HSCP 97, 197-214.

Trevizam, M. - Raimundo, R. de F. M. 2011. 'Papéis de Baco em Geórgicas II: figuraçao poética, religiosidade e história do teatro.' Nuntius Antiquus 7, 79-103.

Viré, Gh. (ed.) 1992. Hyginus, De astronomia. Stuttgart and Leipzig.

Weber, C. 2002. 'The Dionysus in Aeneas.' CPh 97, 322-43.

Winkler, J. J. 1990. 'The Ephebes' Song.' In J. J. Winkler - F. I. Zeitlin, edd. Nothing to Do with Dionysos? Princeton, 20-62.

Wyler, S. 2004. '<<Dionysos Domesticus>>. Les motifs dionysiaques dans les maisons pompéiennes et romaines (Iie s. av.-1er s. ap. J.-C.).' MEFR 116, 933-951.

Wyler, S. 2005. 'Le décor dionysiaque de la villa de la Farnésine, ou l'art de faire grec à Rome.' Métis N. S. 3, 101-129.

Wyler, S. 2006. 'Images dionysiaques à Rome: à propos d'une fresque méconnue de Lanuvium.' In C. Bonnet - P. Scarpi - J. Rüpke (eds.), Religions orientales, culti misterici, Mysterien. Nouvelles perspectives, nuove perspettive, neue Perspektiven. Stuttgart, 135-145.

Wyler, S. 2008. 'Réhabilitation de Liber : ambiguïtés de la condamnation des images dionysiaques, de "l'affaire” des Bacchanales à Actium.' In S. Benoist - A. Daguet-Gagey (edd.), Un discours en images de la condamnation de mémoire, Metz, CRULH 34, 229-244.

Wyler, S. 2013a. 'An Augustan Trend Towards Dionysos: Around the 'Auditorium of Maecenas.' In A. Bernabé - M. Herrero de Jáuregui - A. I. Jiménez San Cristóbal - R. Martín Hernández (eds.), Redefining Dionysos. Berlin and Boston, 541-53.

Wyler, S. 2013b, 'Dionysos/Loufir/Liber et sa parèdre. Le fronton du temple et le culte de S. Abbondio.' MEFR 125, 1-18.

Wyler, S. forthcoming. Les images de Liber. Perceptions du dionysisme dans la Rome républicaine et augustéenne. Rome.

Zanker, P. 1998. Eine Kunst für die Sinne: zur Bilderwelt des Dionysos und der Aphrodite. Berlin.

\section{NOTES}

1. Castriota 1995, 87-106; Sauron 2000; Miller 2002; Wyler 2005, 2006, 2008, 2013a, and (forthcoming); Fabre-Serris 2009; Freyburger-Galland 2009; Schiesaro 2009; Feldherr 2010; Fuhrer 2011; Pollini 2012; Freyburger 2013; Giusti (forthcoming). For an incisive and wide-ranging earlier treatment see Becher 1976.

2. On Bacchus in Virgil see Weber 2002; Krummen 2004; Bocciolini Palagi 2007; Cucchiarelli 2011 and 2012; Henrichs 2013; Mac Góráin 2013 and 2014. For recent treatments of Bacchus in the Georgics see Morgan 1999, esp. 230-5; Hardie 2002, 175-81; Smith 2007; Johnston 2009, 253-6; Schiesaro 2009, 77-9; Cucchiarelli 2011, 250-60; Trevizam - Raimundo 2011; and Gowers (forthcoming). 
3. The main primary references are as follows: fertility 1.7 and passim; ritual: 1.166, 2.380-96, 529; 4.520-2; poetic inspiration: $2.1-8,486-9$; 3.43 ; politics as such is harder to pin on any specific passage, but it will become clear during my discussion that some passages lend themselves to political interpretation in light of the poem's context.

4. For the 'Auditorium of Maecenas' see Wyler 2013a; for the Villa Farnesina, possibly owned by Agrippa and Julia, see Sauron 1994, 573-7; Wyler 2005.

5. See Wyler 2013a, 546.

6. Servius Danielis ad Aen. 8.310, hoc etiam Maecenas in Symposio, ubi Vergilius et Horatius interfuerunt, cum ex persona Messalae de vi vini loqueretur, ita: 'ut idem umor ministrat faciles oculos, pulchriora reddit omnia et dulcis iuventae reducit bona.'

7. See Pliny NH 35.131 with Kellum 1990, 282-3.

8. On the relationship between the Dionysian and Apolline plants see Kellum 1994, 31-3; Castriota 1995, esp. 106; Sauron 2000, 81-2; Pollini 2012, 271-308.

9. Smith 2007; see also Castriota 1995, 105, and passim.

10. See Cucchiarelli 2011, 230-50; 2012, passim, and 2012a.

11. See Plut. Ant. 75, 3-7 with Rose 1924, Scott 1929, and Pelling 1988, 303-4.

12. Miller 2002, 204, with broader considerations on Bacchus and the Augustan regime; Zanker 1998, 109. On the temple see Coarelli 1993.

13. Cic. Laws 2.35-7, Quid ergo aget Iacchus Eumolpidaeque uostri et augusta illa mysteria, si quidem sacra nocturna tollimus? [...] Nam mihi cum multa eximia diuinaque uide $<a>n t u r$ Athenae tuae peperisse atque in uitam hominum attulisse, tum nihil melius illis mysteriis, quibus ex agresti immanique uita exculti ad humanitatem et mitigati sumus, initiaque, ut appellantur, ita re uera principia uitae cognouimus, neque solum cum laetitia uiuendi rationem accepimus, sed etiam cum spe meliore moriendi. [...] Quo in genere seueritatem maiorum senatus uetus auctoritas de Bacchanalibus et consulum exercitu adhibito quaestio animaduersio<que> declarat.

14. Cic. De natura deorum 2.62; see 3.58 for a more esoteric consideration of the different versions of Dionysus. For Iacchus identified with Dionysus see Soph. Ant. 1152; Virg. Ecl. 6.15, and Kern $1916,619$.

15. For the literary resonances of coturnis see Thomas $1988 \mathrm{ad}$ loc.; for treading the grapes as a metaphor for poetic composition, which aligns god and poet, see Deremetz 2000, 173.

16. See Gowers (forthcoming) on Bacchus as an appropriate figure for the ungovernable pullulating structure of Book 2.

17. cui super (373), nec tantum ... quantum (376-8), non aliam ob culpam (380), et (381), atque (383), nec non (385), hinc (390), ergo (388).

18. See Trevizam - Raimundo $2011,99$.

19. 1.163-6, tardaque Eleusinae matris uoluentia plaustra, ... uirgea praeterea Celei uilisque supellex, I arbuteae crates et mysticauannus Iacchi ...

20. See Klingner 1967, 261 for the idea of the god's epiphany in this line.

21. For Bacchus-Ceres pairings see Eur. Ba. 276; Lucr. 5.14; Tibullus 2.1; and Virgil's model Varro, RR, I, 5: tertio Cererem et Liberum, quod horum fructus maxime necessari ad victum; ab his enim cibus et potio venit e fundo.

22. This tradition was old in Pliny's time, ut veteres dixere, $N H$ 3, 60.

23. See Meuli 1955, 226-7 for the ancient sources, which include Hor. AP 220; cf. Winkler 1990, 58-9.

24. Varr. RR. 1.2.19, sic factum ut Libero patri, repertori vitis, <h>irci immolarentur, proinde ut capite darent poenas; Mynors cites CIL 4 (2) 3407 (the poem from Pompeian painting of a goat, quoted in body text, above) and CIL 6 (2) 9632; one might add CIL 6 (2) 468 from 98AD, a dedication performed on the Ides of October, the festival of the vindemia and Virgil's birthday.

25. Anth. Gr. 9.75; mentioned also in schol. Aristoph. Plut. 1129 and Suet. Dom. 14.2.

26. F. 1.357-8; cf. Geo. 2.395, stabit sacer hircus ad aram; cf. also Ov. Met. 15.115 and Mart. Ep. 3.24. 
27. Meuli 1955.

28. Suet. DA 31.4, nonnulla etiam ex antiquis caerimonis paulatim abolita restituit, ut ... ludos Saeculares et Compitalicios. [...] Compitales Lares ornari bis anno instituit uernis floribus et aestiuis. The beginning of Ch. 31 suggests that Augustus did not undertake these reforms until assuming the office of Pontifex Maximum on the death of Lepidus in 13 BCE.

29. For Liberalia see Varro, LL 6.14, Liberalia dicta, quod per totum oppidum eo die sedent sacerdotes Liberi anus hedera coronatae cum libis et foculo pro emptores sacrificantes; cf. Ov. F. 3.726 liba, 728 Liber, and 733-6 nomine ab auctoris ducunt libamina nomen / libaque, quod sanctis pars datur inde focis; / liba deo fiunt, sucis quia dulcibus idem / gaudet, et a Baccho mella reperta ferunt.

30. 382 inter pocula laeti, 386 risuque soluto $\sim$ verbis flagitiosissimis.

31. Cf. 390 hinc omnis pubescit uinea fetu with pro eventibus seminum.

32. 382 pagos et compita circum Italiae compitis ... prius rure in compitis et usque in urbem postea vectabatur.

33. The first publication of this painting was Atteni 2002; for a full description and analysis see Wyler 2006; there is a vivid colour picture in Wyler 2013b, 11, fig. 46. The painting is dated to between 20 and $10 \mathrm{BCE}$ on stylistic grounds.

34. See Maass 1883, 114-5; Solmsen 1947, 270-1; Meuli 1955, 206-11; Frentz 1967, 20; Shechter 1975, 374-8; Mynors 1990, ad loc.; Hollis 1991; Erren 2003, 462; Thibodeau 2011, 94-7.

35. The main sources are Hyginus, De Astronomia 2.4 and Fabulae 130, and Nonnus, Dionysiaca 47.34-264.

See Maass 1883; Solmsen 1947; Merkelbach 1963; and most conservatively Geus 2002, 100-110.

36. See Frentz 1967, 17-27. 1.33, qua locus Erigonen inter Chelasque; 1.218, Taurus et auerso cedens Canis occidit astro; 1.229 , haud obscura cadens mittet tibi signa Bootes.

37. Frentz 1967, 6-27.

38. The Aiôra, or swinging festival in honour of Erigone is mentioned at Aetia fr. 178.3-4; see Harder 2012, 2.958 and 962-3 on the references to this and other Dionysian festivals in fr. 178.

39. See Thibodeau 2011, 96.

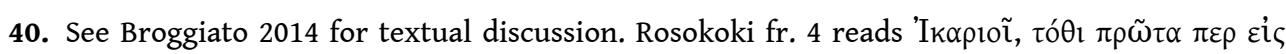

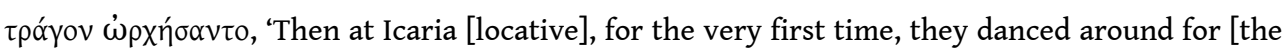
prize of] a goat.' Hopkinson 1997, 30 notes that the line has no caesura, and finds the Homeric

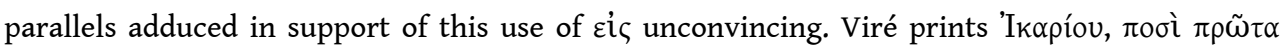

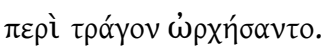

41. The tradition goes back to certain 'alii' known to Servius on 2.454. See Thomas ad loc. for a summary; the tradition continues with Erren 2003, 505, 'Auch dieses Schlußbildchen muß man mit Humor betrachten.'

42. See Gale 2000, 72-5.

43. See Thomas $1995,205-9$ on possible Callimachean allusion in the artfully ordered pairing of Ceres and Liber.

44. Nappa 2005, 97-100.

45. E.g. Smith 2007, 74; Cucchiarelli 2011, 256-7.

46. Odysseus gives unmixed wine to the Cyclops at 9.345, a wine that was normally diluted in the ratio of one cup to twenty cups of water (9.210). See Eur. Cycl. 556-60.

47. The sources are Athen. Deipn. 2.4; Stob., Anth. 3.18.3; and Anth. Graec. Appendix 68; cf. similar but not identical lines at Clem. Alex. Paed. 2.2.28.2.

48. See Rosokoki ad loc with Hopkinson 1997, 30.

49. Thibodeau 2011, 96.

50. See Rosokoki 1995, 17-8.

51. See Nock 1928, 21-30; Bosworth 1980, II, 201; Goukowsky 1981.

52. See Loeb, Select Papyri, vol. 2, 208.

53. Plut. Alex. 13; Arrian, Anab. 4.8-9; Curtius 8.2.6. 
54. I owe this point to Elias Koulakiotis' unpublished paper, 'Alexander and Dionysos: Royal ideology and after-life representations in ancient Macedonia', delivered in Senate House, London, on 3 March 2011.

55. Grimal 1980, 184-5 reads the vituperatio vini against the background of against Antony's Dionysian posturing.

56. Plut. Ant. 24, 4.

57. Scott 1929 has largely commanded agreement and is often cited; see Marasco 1992.

58. Smith 2007, 81-2.

59. I would like to thank an audience at the University of Lille III - Charles de Gaulle, especially Alain Deremetz, for their input into this paper; my thanks also to several scholars whose generous comments on earlier versions have improved this paper considerably: Andrea Cucchiarelli, Elena Giusti, Patricia Johnston, Tom Mackenzie, Richard Thomas, and the anonymous readers for Dictynna.

\section{ABSTRACTS}

A certain Augustan 'rehabilitation' of Bacchus may be traced in Virgil's Georgics, in response to the god's role in the self-presentation of Mark Antony, especially with reference to the movement on the worship of Bacchus in Book 2. An analysis of the ritual elements is offered here. Nonetheless, certain references to Bacchus in the Georgics suggest that he is a volatile symbol, difficult to control: some of these reside in Virgil's allusions to Eratosthenes' Erigone.

\section{INDEX}

Mots-clés: Antony, Augustus., Bacchus, Dionysus, Eratosthenes, Erigone, Georgics, Liber, politics, ritual, Virgil 